\title{
Modifikasi Kitin Hasil Isolasi Autolisis Dari Limbah Udang Putih (Litopenaeus vannamei) Dengan Anhidrida Maleat
}

\author{
(Modification of Chitin Produced by Autolysis Isolation of White Shrimp Waste \\ (Litopenaeus vannamei) With Maleic Anhydride)
}

\author{
Chanifah Dwi Happy Pratiwi, Busroni, Achmad Sjaifullah*) \\ Jurusan Kimia, Fakultas Matematika dan Ilmu Pengetahuan Alam, Universitas Jember \\ J1. Kalimantan 37 Jember 68121 \\ ${ }^{*}$ Penulis Korespondensi E-mail: sjaiful.fmipa@unej.ac.id
}

\begin{abstract}
Abstrak
Limbah udang banyak mengandung protein, mineral dan kitin sehingga dapat dijadikan sebagai sumber kitin. Kitin pada limbah udang dapat diisolasi secara kimiawi dan enzimatis. Isolasi secara kimiawi memberikan dampak yang kurang baik terhadap lingkungan karena penggunaan bahan-bahan kimia untuk mengisolasi kitin tersebut akan menghasilkan limbah yang dapat mencemari lingkungan. Oleh karena itu isolasi kitin dilakukan secara enzimatis autolisis untuk mengurangi penggunaan bahan kimia dengan menggunakan enzim protease yang terdapat dalam limbah udang itu sendiri dengan cara diblender dan diinkubasi selama 10 hari pada pH 2 menggunakan asam fosfat. Kitin hasil isolasi mengandung kadar $\mathrm{N} \mathrm{6,6 \%}$ pada hari terakhir inkubasi. Kitin yang diperoleh diturunkan menjadi kitin maleat dengan memanaskan kitin dan anhidrida maleat pada fase padat pada suhu $120^{\circ} \mathrm{C}$ dalam waktu 3,5 jam. Modifikasi kitin menjadi kitin maleat digunakan untuk meningkatkan sifat hidrofilistas kitin. Karakterisasi FTIR dari kitin yang dimodifikasi dengan anhidrida maleat menunjukkan terbentuknya gugus fungsi baru yaitu ikatan ester yang ditunjukkan oleh vibrasi dari $-\mathrm{C}=\mathrm{O}$ ester pada bilangan gelombang $1712 \mathrm{~cm}^{-1}$. Uji peningkatan hidrofilisitas dilakukan melaui uji daya serap air untuk mengetahui kemampuan kitin maleat dalam menyerap air. Kitin mempunyai daya serap air $0,97 \mathrm{~g} / \mathrm{g}$ sedangkan kitin maleat yaitu $2,78 \mathrm{~g} / \mathrm{g}$. Gugus karboksilat $(-\mathrm{COOH})$ yang terikat pada kitin maleat yang menyebabkan meningkatnya kemampuan daya serap air kitin maleat karena adanya gugus karboksilat (-COOH) yang bersifat hidrofilik.
\end{abstract}

Kata Kunci: Autolisis, Kitin, Kitin maleat, Limbah udang.

Abstract

Shrimp waste is many containts of protein, mineral and chitin so that it can be used as chitin sources. Chitin in shrimp waste can be isolated chemically and enzymatically. Chemical isolation is giving adverse effect on the environment because the use of chemicals to isolate chitin will produce waste that can polute environment. Therefore chitin isolation was carried out by enzymatic autolysis for reduce use of chemicals by using protease enzymes derived from the waste itself with blended and incubated for 10 days at pH 2 using fosfat acid. Isolated chitin is containt 6,6\% $\mathrm{N}$ on the 10th day of incubation. Isolated chitin was modified to maleic chitin by heating chitin and anhydride maleat at the solid state at temperature $120^{\circ} \mathrm{C}$ for 3,5 hours. Modification is used to improve hydrophilicity of chitin. Characterization of FTIR from chitin modified with maleic anhydride showed the formation of a new functional group is a ester bond that shown by vibrations from $-C=O$ esters at wave number $1712 \mathrm{~cm}^{-1}$. The hydrophilicity increase test was doing with a water absorption test. Chitin has a water absorption of $0,97 \mathrm{~g} / \mathrm{g}$ while meleic chitin is $2,78 \mathrm{~g} / \mathrm{g}$. The carboxilyc groups are bound at maleic chitin which increase the ability of water absorption from chitin because the carboxilyc groups is a hydrophilic group.

Keywords: Autolysis, Chitin, Maleic chitin, Shrimp waste.

\section{PENDAHULUAN}

Budidaya udang tambak di Indonesia telah berkembang pesat karena udang merupakan salah satu dari biota laut yang mempunyai nilai ekonomis tinggi serta merupakan komoditi ekspor yang dapat diandalkan salah satunya yaitu udang putih (Litopenaeus vannamei). Ekspor udang di Indonesia dilakukan dalam bentuk udang beku yang telah dibersihkan kulit, kepala serta ekornya. Produksi udang putih pada tahun 2011 mencapai 246.420 ton dan mengalami kenaikan 2 kali lipat pada tahun 2014 yaitu mencapai 442.380 ton[1]. Peningkatan permintaan pasar akan meningkatkan jumlah produksi udang beku yang menyebabkan limbah udang yang dihasilkan semakin banyak. Limbah udang yang dihasilkan yaitu antara $35-50 \%$ dari berat utuh udang[2]. Limbah udang yang dihasilkan dari proses pembekuan udang dapat menyebabkan pencemaran lingkungan karena dapat meningkatkan biological oxygen demand (BOD) dan chemical oxygen demand (COD) dalam perairan serta menimbulkan bau yang dapat menyebabkan polusi udara[3]. Pemanfaatan limbah udang selama ini belum dilakukan secara maksimal karena hanya digunakan sebagai pakan ternak, kerupuk udang, tepung kulit udang, serta sebagai bahan pembuatan terasi. Limbah udang sendiri mengandung protein $(53,74 \%)$,kitin $(14,61 \%)$, lemak $(6,65 \%)$, air $(17,28 \%)$ serta abu (7,72\%) dari berat basah [4], sehingga limbah udang dapat dijadikan sebagai sumber kitin. Kitin sendiri 
merupakan suatu polimer karena mengandung unit pengulangan berupa $\mathrm{N}$-asetil glukosamin yang terikat melalui ikatan (1-4) $\beta$ - glikosidik. Struktur kitin berupa rantai panjang yang hampir sama dengan selulosa. Kitin dan selulosa mempunyai monomer-monomer yang saling berikatan melalui ikatan glikosida. Kitin mengandung gugus asetamida (-NHCOCH3) pada atom karbon nomer 2 sedangkan selulosa mengandung gugus hidroksi $(-\mathrm{OH})$ [5]

Budidaya udang tambak di Indonesia telah berkembang pesat karena udang merupakan salah satu dari biota laut yang mempunyai nilai ekonomis tinggi serta merupakan komoditi ekspor yang dapat diandalkan salah satunya yaitu udang putih (Litopenaeus vannamei). Ekspor udang di Indonesia dilakukan dalam bentuk udang beku yang telah dibersihkan kulit, kepala serta ekornya. Produksi udang putih pada tahun 2011 mencapai 246.420 ton dan mengalami kenaikan 3 kali lipat pada tahun 2019 yaitu mencapai 700.380 ton. Peningkatan permintaan pasar akan meningkatkan jumlah produksi udang beku yang menyebabkan limbah udang yang dihasilkan semakin banyak. Limbah udang yang dihasilkan yaitu antara $35-50 \%$ dari berat utuh udang[2]. Limbah udang yang dihasilkan dari proses pembekuan udang dapat menyebabkan pencemaran lingkungan karena dapat meningkatkan biological oxygen demand (BOD) dan chemical oxygen demand (COD) dalam perairan serta menimbulkan bau yang dapat menyebabkan polusi udara [3]. Pemanfaatan limbah udang selama ini belum dilakukan secara maksimal karena hanya digunakan sebagai pakan ternak, kerupuk udang, tepung kulit udang, serta sebagai bahan pembuatan terasi[4]. Limbah udang sendiri mengandung protein $(53,74 \%)$,kitin $(14,61 \%)$, lemak $(6,65 \%)$, air $(17,28 \%)$ serta abu $(7,72 \%)$ dari berat basah [4]. sehingga limbah udang dapat dijadikan sebagai sumber kitin. Kitin sendiri merupakan suatu polimer karena mengandung unit pengulangan berupa $\mathrm{N}$-asetil glukosamin yang terikat melalui ikatan (1-4) $\beta$ - glikosidik. Struktur kitin berupa rantai panjang yang hampir sama dengan selulosa. Kitin dan selulosa mempunyai monomer-monomer yang saling berikatan melalui ikatan glikosida. Kitin mengandung gugus asetamida (-NHCOCH3) pada atom karbon nomer 2 sedangkan selulosa mengandung gugus hidroksi (-OH) [6] $\left(\mathrm{H}_{2} \mathrm{SO}_{4}\right)$ untuk proses deprotenasi dan demineralisasi Isolasi kitin secara enzimatis dapat dilakukan dengan memanfaatkan enzim protease yang berasal dari luar maupun yang berasal dari dalam udang itu sendiri. Isolasi kitin secara enzimatis sebelumnya telah dilakukan Juniarso [6] dengan memanfaatkan enzim protease yang disolasi dari perut ikan lemuru. Isolasi kitin secara kimiawi memberikan dampak yang kurang baik terhadap lingkungan. Hal ini disebabkan karena penggunaan bahan-bahan kimia untuk mengisolasi kitin tersebut akan menghasilkan limbah yang dapat mencemari lingkungan, oleh karena itu isolasi kitin dilakukan secara enzimatis autolisis untuk mengurangi penggunaan bahan kimia yaitu dengan menggunakan enzim protease yang terdapat dalam limbah udang itu sendiri. Isolasi kitin secara autolisis enzimatis dilakukan dengan merendam limbah udang yang telah dihaluskan dalam larutan asam fosfat dan dikondisikan $\mathrm{pH}$ nya hingga $\mathrm{pH} 2$ dan diinkubasi selama 10 hari dalam wadah tertutup sehingga $\mathrm{pH} 2$ digunakan untuk menekan pertumbuhan bakteri yang dapat menyebabkan pembusukan pada limbah udang [7] .

Kitin hasil isolasi dimodifikasi dengan anhidrida maleat untuk meningkatkan sifat hidrofilisitas dari kitin. Modifikasi kitin dengan anhidrida maleat sebelumnya telah dilakukan oleh Uzun dan Celik [8] dengan melarutkan kitin dalam suatu larutan litium klorida/N,N- dimetilasetamida sehingga kitin yang direaksikan dengan anhidrida maleat berada pada fase aqueous (aq). Kitin maleat yang dihasilkan mengandung pengotor yang dideteksi sebagai asam klorida hidrat $\left(\mathrm{HCl} . \mathrm{H}_{2} \mathrm{O}\right)$ yang diserap oleh kitin maleat karena $\mathrm{HCl}$ dan air digunakan dalam sintesis kitin maleat. Sintesis kitin maleat pada penelitian ini dilakukan pada fase padat untuk mengurangi biaya penggunaan bahan kimia serta agar lebih mudah dalam memurnikannya. Kitin dan kitin maleat yang dihasilkan dari penelitian dikarakterisasi menggunakan FTIR.Uji peningkatan sifat hidrofilisitas dari kitin dilakukan melalui pengukuran daya serap air pada kitin dan kitin maleat. Dengan diturunkannya kitin menjadi kitin maleat yang mempunyai gugus samping yang lebih hidrolfilik dari pada kitin maka akan diperoleh turunan kitin yang lebih besar hidrofilisitasnya. Turunan kitin yang lebih bersar hidrofilisitasnya, diharapkan mempunyai applikasi yam lebih luas dari pada kitin. Turunan kitin yang lebih bersar hidrofilisitasnya akan lebih mudah larut dalam air, mudah dijadikan hidrogel, film ataupun nanosfer yang menjanjikan banyak penggunaan seperti sebagai material biocompatibel pembawa bahan aktif [9],[10], material pengenadli pencemaran lingkungan [11], dan aplikasi lainnya [9].

\section{METODE PENELITIAN}

\section{Alat dan Bahan}

Peralatan yang digunakan dalam penelitian ini adalah peralatan gelas, neraca analitik, blender, satu set alat kjeldhal, $\mathrm{pH}$ meter, toples, cawan porselin, stirer, magnetic stirer, termometer, mortar, alu dan spektrofotometer IR. Bahan yang digunakan pada penelitian ini limbah udang vannamei, akuades, aseton $75 \%, \mathrm{NaOCl} 0,315 \%$, anhidrida maleat, aseton, $\mathrm{NaOH} 1,0 \mathrm{M}, \mathrm{CuSO} 4$ (pa), Na2SO4 (pa), H2SO4 (pa), H3BO3 $4 \%$, indikator metil merah-metil biru, $\mathrm{NaOH} 40 \%, \mathrm{HCl} 0,01 \mathrm{~N}, \mathrm{HCl} 1 \mathrm{~N}$, H3PO4 8,5\%, tea bag, kertas pH dan kertas saring.

\section{Isolasi Kitin Secara Autolisis}

Limbah udang berupa kepala dan kulit udang dibersihkan kemudian ditimbang sebanyak 857,30 gram dan dihaluskan menggunakan blender. Sampel selanjutnya diasamkan hingga $\mathrm{pH} 2$ menggunakan asam fosfat kemudian diinkubasi selama 10 hari dalam wadah tertutup rapat. Sampel diaduk sesekali dan dijaga $\mathrm{pH}$ nya agar tidak berubah dengan menambahkan asam fosfat jika dibutuhkan. Sampel dicuci menggunakan akuades hingga netral setelah inkubasi selama 10 hari dan di saring. Residu yang diperoleh dikeringkan dalam oven pada suhu $600 \mathrm{C}$ selama 24 jam kemudian didemineralisasi menggunakan $\mathrm{HCl} 1 \mathrm{~N}$ $(1: 10 \mathrm{~b} / \mathrm{v})$ dan diaduk menggunakan stirer selama 1 jam pada suhu 75oC. Sampel selanjutnya didepigmentasi dengan aseton $75 \%(1: 10 \mathrm{~b} / \mathrm{v})$ dan $\mathrm{NaOCl} 0,315 \%(1: 10$ 
b/v) diaduk selama 1 jam. Sampel kemudian dicuci dengan akuades hingga sampel netral kemudian disaring. Residu yang didapatkan dikeringkan pada suhu $600 \mathrm{C}$ selama 24 jam kemudian setelah kering ditimbang dan dilakukan uji analisis spektroskopi IR serta uji daya serap air [12].

\section{Modifikasi Kitin dengan Anhidrida Maleat}

Kitin yang sudah dihaluskan dengan ukuran 120 mesh ditimbang sebanyak 2,00 gram kemudian direaksikan dengan anhidrida maleat 16,00 gram pada suhu $1200 \mathrm{C}$ dalam waktu 3,5 jam dan diaduk sesekali. Campuran disaring dan dicuci menggunakan aseton serta akuades hingga filtrat yang dihasilkan netral. Residu yang diperoleh dicuci dengan $\mathrm{NaOH}$ 1,0 M sebanyak 10-15 mL kemudian dicuci menggunakan akuades hingga $\mathrm{pH}$ mencapai 7,8. Sampel kemudian di saring dan residu yang didapatkan dikeringkan [13].

\section{Analisis Kadar Nitrogen (N) dengan Metode Kjeldhal}

Sampel sebanyak 1,00 gram dimasukkan ke dalam labu kjehdhal kemudian ditambahkan $\mathrm{CuSO} 4$ 0,4 gram dan Na2SO4 3,5 gram. Campuran tersebut kemudian ditambahkan asam sulfat pekat (98\%) sebanyak $12 \mathrm{~mL}$ secara hati-hati kemudian digojok. Campuran di destruksi menggunakan lemari asam hingga berwarna hijau jernih. Hasil destruksi yang didapatkan didinginkan pada suhu ruang dan ditambahkan dengan $25 \mathrm{~mL}$ akuades secara perlahan. Destruat dipindahkan ke dalam labu destilasi dan ditambahkan $\mathrm{NaOH} \quad 40 \%$ sehingga larutan berwarna kecoklatan kemudian didestilasi. Destilat yang dihasilkan ditampung menggunakan erlenmeyer yang telah berisi dengan $10 \mathrm{~mL} \mathrm{H} 3 \mathrm{BO} 34 \%(\mathrm{~b} / \mathrm{v})$ serta indikator metil merah : metil biru sebanyak 2-4 tetes sampai asam borat berwarna keunguan. Labu destilasi dipanaskan secara perlahan hingga cairan dalam labu destilasi mendidih. Destilasi dihentikan ketika destilat yang tertampung dalam erlenmeyer berwarna hijau. Hasil yang diperoleh kemudian dititrasi menggunakan $\mathrm{HCl}$ 0,01 N yang telah distandarisasi.

\section{Uji Kadar Air}

Cawan porselin yang sudah dibersihkan dioven selama 3 jam pada suhu 100-1050 C kemudian didinginkan dalam desikator dan ditimbang beratnya. Sampel ditimbang sebanyak 1,00 gram dalam cawan porselin kemudian dioven selama 3 jam pada suhu 100- 1050 C. Sampel kemudian didinginkan dalam desikator kemudian ditimbang beratnya menggunakan neraca analitik. Sampel dipanaskan lagi dalam oven kemudian didinginkan dan hitung beratnya hingga konstan. Kadar air dapat dihitung menggunakan rumus sebagai berikut :

$$
\text { kadar air }=\frac{w_{1}-w_{2}}{w_{1}} \times 100
$$

Dimana $\mathrm{W} 1=$ berat sampel sebelum dikeringkan (gram); W2 = berat sampel setelah dikeringkan (gram).

\section{Spektroskopi Inframerah}

Kitin sebelum dan sesuadah dimodifikasi dengan anhidrida maleat dianalisis gugus fungsinya menggunakan spektroskopi IR untuk mengetahui terjadinya perubahan gugus fungsi pada kitin sesudah dimodifikasi. Spektrum IR diperoleh menggunakan Shimadzu a new generation of IR
Prestige-21 yang dilakukan pada kisaran bilangan gelombang 4000-400 cm-1.

\section{Uji Daya Serap Air}

Uji daya serap air dilakukan dengan metode tea bag. Kitin maleat kering ditimbang sebanyak $\pm 0,1$ gram sebagai W0 kemudian dimasukkan ke dalam kantung teh yang kering kemudian distreples. Kantung teh yang telah berisi kitin maleat direndam dalam akuades $200 \mathrm{~mL}$ selama 2 jam, 24 jam dan 10 hari pada suhu kamar. Kantung kemudian dikeringkan selama 15 menit dengan cara digantung kemudian permukaan luar kantung teh dikeringkan dengan kertas saring untuk menghilangkan air yang tersisa kemudian ditimbang sebagai Ws setelah kering. Kantung teh kosong yang telah direndam tersebut kemudian ditimbang sebagai Wf. Daya serap air dihitung berdasarkan persamaan :

$$
Q=\frac{W_{s}-W_{0}-W_{f}}{W_{0}}
$$

Dimana $\mathrm{Q}=$ daya serap ; $\mathrm{WS}=$ massa kantung teh berisi kitin maleat yang telah di rendam $(\mathrm{g})$;

$\mathrm{W}_{\mathrm{F}}=$ massa kantung teh kosong yang telah di rendam $(\mathrm{g}) ; \mathrm{W}_{0}=$ massa kitin maleat kering $(\mathrm{g})$ [10].

\section{HASIL DAN PEMBAHASAN}

\section{Analisis Kadar Nitrogen (N) dengan Metode Kjeldhal}

Kadar $\mathrm{N}$ dalam limbah cangkang udang yang diperoleh dalam penelitian ini, yaitu saat waktu inkubasi 0 jam (hari ke-1) adalah sebesar 8,6\% dan pada hari ke-10 sebesar 6,6 $\%$. Hasil yang diperoleh sangat bersesuaian dengan dengan kadar $\mathrm{N}$ yang dihasilkan dari penelitian yang telah dilaporkan oleh Sjaifullah dan Santoso (2015) yaitu 8,5\% pada saat 0 jam (hari ke-1) serta $6,5 \%$ pada hari ke- 10 . Hal ini menunjukkan bahwa proses autolisis limbah udang pada pH 2 selama 10 hari inkubasi dalam lingkungan asam fosfat memberikan hasil yang konsisten.

\section{Kitin dan Kitin Maleat}

Kitin yang dihasilkan dari limbah kulit udang putih melalui proses diproteinasi secara enzimatik selama autolisis, kemudian dicuci dan didepigmentasi. Secara visual dapat dilihat di gambar 1c, kitin dari limbah kulit udang putih yang dihasilkan setelah proses pencucian, dimineralissi dan depigmentasi terlihat lebih putih dari pada sebelum dilakukan depigmentasi, yaitu baik setelah tahan deproteinasi maupun setelah tahap deminiralisasi seperti ditunjukkan dalam Gambar 1.

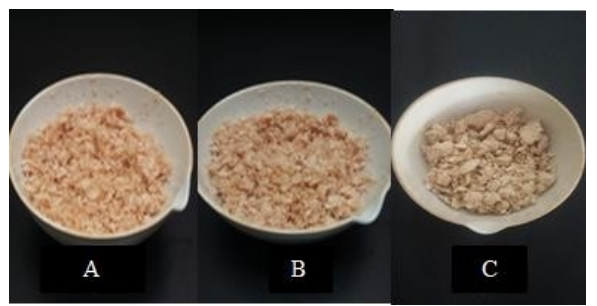

Gambar 1. Hasil deproteinasi (A), Demineralisasi (B), Depigmentasi (C)

Kitin yang dimodifikasi dengan anhidrida maleat pada fase padat dengan pemanasan pada suhu $120 \mathrm{oC}$ selama 3,5 
jam dan sesekali dilakukan pengadukan yang bertujuan untuk mencapurkan serbuk kitin dengan anhidrida maleat agar reaksi terjadi secara menyeluruh serta kelebihan anhidrida maleat yang tidak bereaksi dihilangkan melalui proses pencucian dengan $\mathrm{NaOH} 1 \mathrm{M}$ hingga $\mathrm{pH} 11$ dan diikuti dengan netralisisai secara fisik terlihat sebagai zat berbeda dengan kitin, seperti ditunjukkan dalam Gambar 2.

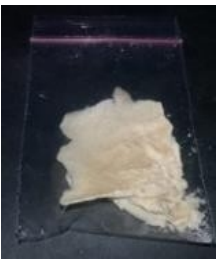

Gambar 2. Kitin Maleat

\section{Karakterisasi FTIR (Fourier transform infrared spectometer)}

Spektra IR kitin seperti dalam gambar 1c dan kitin maleat seperti dalam gambar 2 yang dihasilkan ditunjukkan Gambar 3.

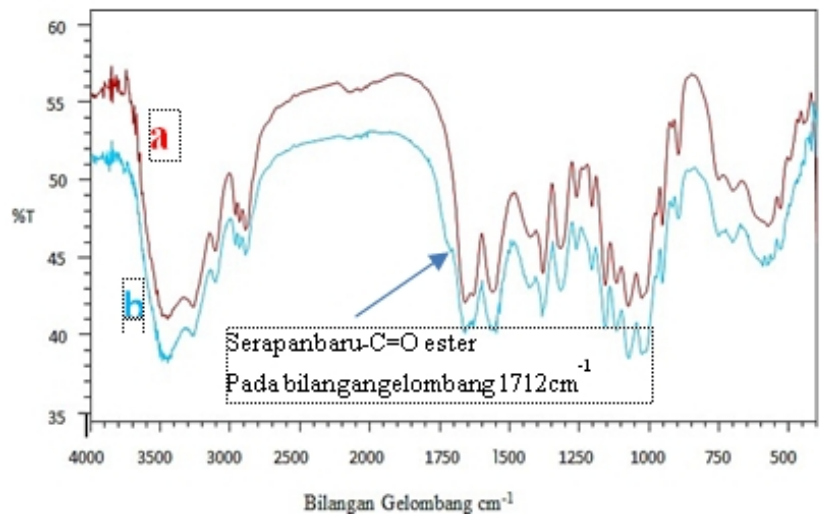

Gambar 3. Spektra IR (a) Kitin Dan (b) Kitin Maleat

Sebelum kitin dimodifikasi dengan anhidrida maleat (Gambar 3a) menujukkan serapan IR pada bilangan gelompan sesuai dengan gugus hidroksi ( $-\mathrm{OH})$ yang muncul pada bilangan gelombang $3448,84 \mathrm{~cm}-1$ bentuk sinyal yang lebar. Adanya gugus asetamida pada spektrum ditunjukkan dengan munculnya streching $\mathrm{C}=\mathrm{O}$ amida pada bilngan gelombang $1658,84 \mathrm{~cm}-1$ serta vibrasi dari $\mathrm{N}-\mathrm{H}$ bending yang muncul pada bilangan gelombang 1558,54 cm-1 yang diperkuat dengan munculnya streching $\mathrm{N}-\mathrm{H}$ pada bilangan gelombang $3261,74 \mathrm{~cm}-1$ dan $3105,5 \mathrm{~cm} 1$. Hasil yang di dapatkan tersebut sesuai dengan yang sudah dilaporkan oleh Trung dan Bao [14] seperti yang ditampilkan dalam Tabel 1.

Tabel 1. Data serapan IR Kitin

\begin{tabular}{|c|c|c|}
\hline \multirow[t]{2}{*}{ Jenis Vibrasi } & \multicolumn{2}{|c|}{ Bilangan gelombang (cm-1) } \\
\hline & Kitin, (Gambar 3a) & Kitin [14] \\
\hline Streching $-\mathrm{OH}$ & 3448,84 & \\
\hline Streching $-\mathrm{CH}$ & 2891,39 & \\
\hline $\begin{array}{l}\text { Streching- } \mathrm{C}=\mathrm{O} \\
\text { amida }\end{array}$ & \multicolumn{2}{|c|}{1658,84 dan 1629,91660 dan 1626} \\
\hline Bending $-\mathrm{NH}$ & 1558,84 & \\
\hline Bending $-\mathrm{CH}$ & 1381,08 & \\
\hline
\end{tabular}

Kitin yang telah dimodifikasi dengan anhidrida maleat mempunyai gugus fungsi baru berupa ikatan ester yang ditunjukkan adanya serapan baru pada bilangan gelombang $1718 \mathrm{~cm}-1$ seperti tampak dalam gambar 3b, sehinmgga gambar 3 menunjukkan adanya perbedaan spektrum IR antara (a) Kitin dan (b) kitin maleat. Adanya serapan IR pada bilangan gelombang $1712 \mathrm{~cm}$ kitin maleat telah dilaporkan oleh Wang [15] yang disebutkan sebagai serapan $\mathrm{C}=\mathrm{O}$ ester kitin maleat. Meskipun ada sedikit perbedaan harga serapan $-\mathrm{C}=\mathrm{O}$ ester namun terletak dalam rentang yang masih bisa diterima. Jika diperhatikan spektra IR pada gambar $3 \mathrm{~b}$ tidak menunjukkan adanya serapan IR $-\mathrm{C}=\mathrm{C}$ alkena disubstitusi. Hal ini dipastikan karena anhidrida maleat yang terikat pada kitin jumlahnya sangat sedikit serta kemungkinan terjadinya tumpang tindih spektrum dengan $-\mathrm{C}=\mathrm{O}$ amida $(1658,84$ dan $1629,9 \mathrm{~cm}-1)$ yang dapat ditunjukkan dengan spektrum yang terdapat pada bilangan gelombang 1658,84 cm- 1 pada Gambar $3 \mathrm{~b}$.

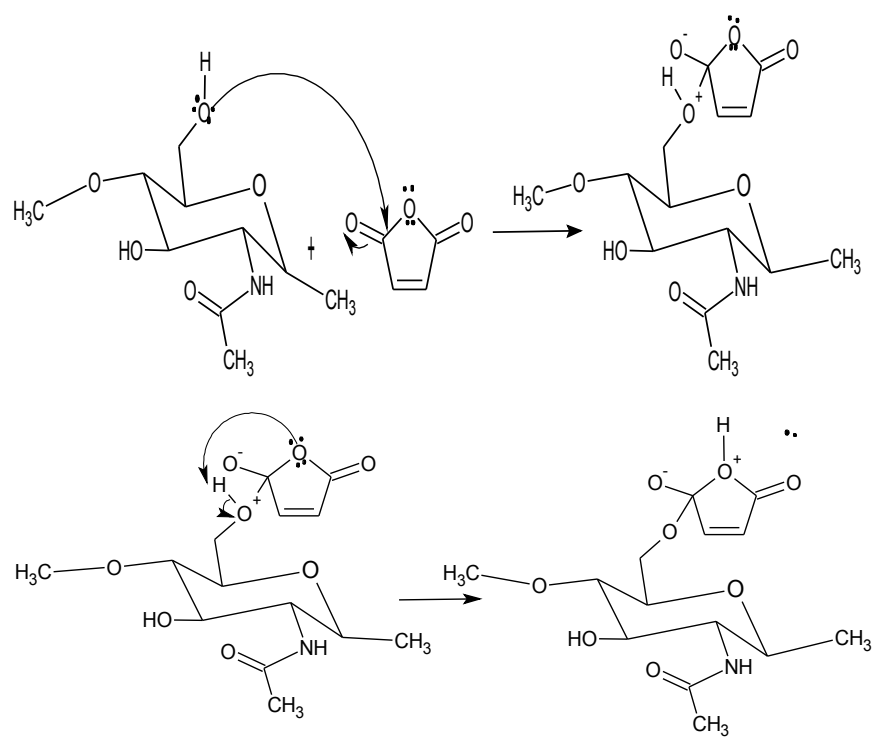

Kitin

Anhidria maleat

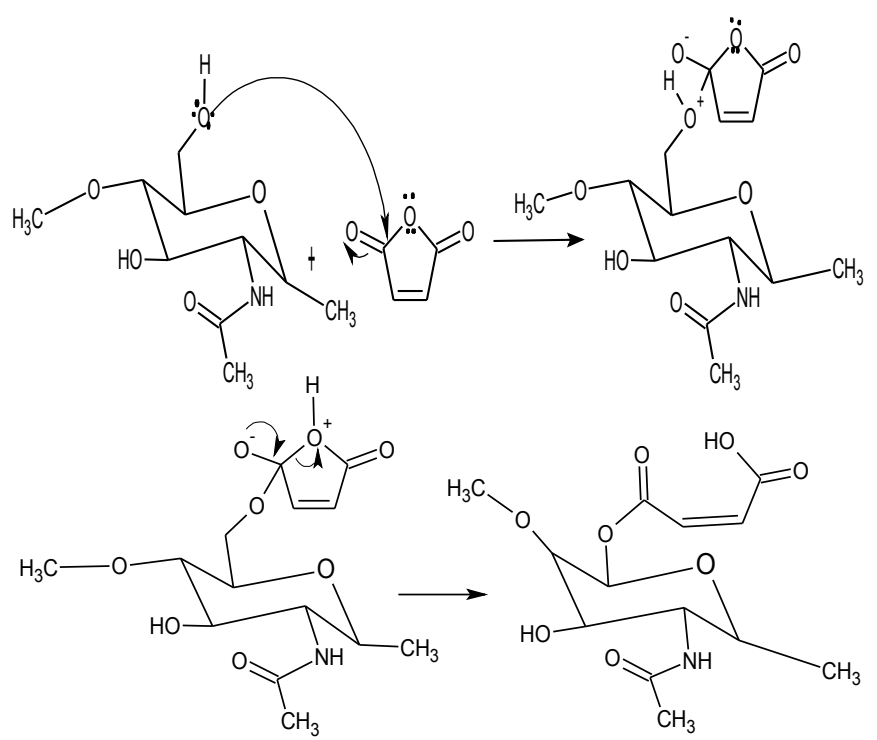

Kitin maleat

Gambar 4. Mekanisme pembentukan kitin maleat 
Kitin maleat terbentuk karena kitin telah bereaksi dengan anhidrida maleat melalui proses pemanasan dalam oven suhu 120o C selama 3,5 jam, sedangkan anhidrida maleat yang tidak bereaksi dengan kitin dicuci menggunakan $\mathrm{NaOH} 1 \mathrm{M}$ sehingga berubah menjadi garam maleat yang larut dalam air. Reaksi yang terjadi antara kitin dengan anhidrida maleat dapat ditunjukkan dalam gambar 4. Reaksi dalam Gambar 4 menunjukkan bahwa antara kitin dengan anhidrida maleat terjadi reaksi esterifikasi yang ditunjukkan dengan terbentuknya ikatan ester pada atom $\mathrm{C}$ nomer 6 dari kitin.

\section{Hasil Uji Daya Serap Air}

Kitin merupakan suatu polimer alam yang bersifat hidrofobik, namun aplikasinya sangat luas[9], sehingga banyak dilakukan untuk memodifikasinya dalam usaha memerbaiki sifatnya yang sesuai dengan yang diinginkan seperti meningkatkan sifat hidrofilisitasnya[16]. Hasil uji daya serap air, yaitu berat air yang dapat diserap oleh setiap satu gram kitin dan kitin maleat, diperoleh bahwa daya serap maksimum dicapai sejak 2 jam pertama, artinya baik kitin maupun kitin maleat telah mencapai daya serap maksimumnya dalam waktu 2 jam. Daya serap air kitin adalah $0,97 \mathrm{~g} / \mathrm{g}$ dan daya serap air kitin maleat adalah 2,78 $\mathrm{g} / \mathrm{g}$. Beradasarkan hasil pengukuran daya serap airnya, diperloeh peningkatan daya serap air maksimum kitin maleat adalah 2,87 kali lebih besar dari pada daya serap air kitin semula. Kenaikan daya serap air kitin maleat menunjukkan hal yang konsisten dengan adanya rantai samping asam maleat yang mempunyai gugus karboksilat ($\mathrm{COOH})$ yang bersifat hidrolfilik dalam rantai kitin seperti ditunjukkan dalam strukturnya dalam Gambar 4. Daya serap air kitin maleat yang diperoleh dalam penelitian ini sebesar $2,78 \mathrm{~g} / \mathrm{g}$, tidaklah sangat besar, pada dasarnya dapat dihubungkan dengan spektrum IR kitin maleat dalam gambar 3b. Serapan IR yang sangat kecil pada bilangan gelombang $1712 \mathrm{~cm}-1$ dari $-\mathrm{C}=\mathrm{O}$ ester rantai samping asam maleat dalam rantai kitin itu menggambarkan jumlah asam maleatnya hanya sedikit atau rantai asam maleat yang sangat pendek. Hal ini juga sangat berhubungan dengan kondisi percobaannya, yaitu reaksi dalam fasa padat antara kitin dengan anhidrida maleat dalam ukuran yang masih sangat kasar, yaitu 120 mesh. Karena itu dalam percobaan berikutnya akan dilakukan dengan membuat ukuran kitin menjadi lebih halus, dan dengan memperpanjang waktu reaksinya serta dengan pengadukan yang lebih baik.

\section{KESIMPULAN}

PHasil modifikasi kitin dengan anhidrida maleat ditunjukkan oleh spektra IR anhidrida maleat yang ditandai dengan munculnya serapan vibrasi dari $-\mathrm{C}=\mathrm{O}$ karbonil ester pada bilangan gelombang $1712,85 \mathrm{~cm}^{-1}$. Daya serap air kitin maleat yang dihasilkan sebesar $2,78 \mathrm{~g} / \mathrm{g}$ bukanlah daya serap air yang besar, meskipun 2,87 kali lebih besar dari pada daya serap air kitin juga sesuai dengan tidak banyaknya asam maleat yang terikat pada rantai kitin seperti ditunjukkan oleh kecilnya serapan IR $-\mathrm{C}=\mathrm{O}$ ester pada bilangan gelombang $1712 \mathrm{~cm}^{-1}$.

\section{UCAPAN TERIMA KASIH}

Penulis mengucapakan terima kasih kepada Direktorat Pendidikan Tinggi, Departemen Pendidikan dan Kebudayaan Republik Indonesia yang telah memberikan dukungan finansial melalui Beasiswa Bidik Misi Tahun 2015-2019.

\section{DAFTAR PUSTAKA}

[1] E. Harpeni, A. Setyawan, L. Santoso, and M. Z. Arifin, "Efektivitas Ekstrak Tepung Ubi Jalar Sebagai Media Teknis Bakteri Probiotik," Proiding Semin. Nas. MIPA, no. Oktober, pp. 27-28, 2016.

[2] R. S. Harjanti, "Kitosan dari Limbah Udang sebagai Bahan Pengawet Ayam Goreng," Kitosan dari Limbah Udang sebagai Bahan Pengawet Ayam Goreng, vol. 8, no. 1, pp. 12-19, 2014.

[3] A. R. Mahyudin and R. Yuliandri, "Isolasi dan Karakteristik Kitin Dari Limbah Udang," J. Sains Nat. Univ. Nusa Bangsa, vol. 1, no. 2, p. 167, 2011.

[4] A. R. Fachry and A. Sartika, "Pemanfaatan Limbah Kulit Udang Dan Limbah Kulit Ari Singkong Sebagai Bahan Baku Pembuatan Plastik Biodegradable," $J$. Tek. Kim., vol. 18, no. 3, pp. 1-9, 2012.

[5] M. Azhar, S. Resmi, and U. Negeri, "Pengaruh Konsentrasi $\mathrm{NaOH}$ dan $\mathrm{KOH}$ Terhadap Derajat Deasetilasi Kitin dari Limbah Kulit Udang," Eksakta, vol. 1, 2010.

[6] E. T. Juniarso, "Pemanfaatn Ekstrak Kasar Protease Dari Isi Perut Ikan Lemuru (Sardinella sp.) Untuk Deproteinasi Limbah Udang Secara Enzimatik Dalam Proses Produksi Kitosan," Skripsi, 2008.

[7] A. Sjaifullah and A. B. Santoso, "Autolytic Isolation of Chitin from White Shrimp (Penaues Vannamei) Waste," Procedia Chem., vol. 18, no. Mcls 2015, pp. 49-52, 2016.

[8] I. Uzun and O. Celik, "Physicochemical characterization and the comparison of chitin and chitin modified with maleic anhydride," Orient. $J$. Chem., vol. 31, no. 2, pp. 619-627, 2015.

[9] H. El Knidri, R. Belaabed, A. Addaou, A. Laajeb, and A. Lahsini, "Extraction, chemical modification and characterization of chitin and chitosan," Int. J. Biol. Macromol., vol. 120, pp. 1181-1189, 2018.

[10] A. Anitha et al., "Chitin and chitosan in selected biomedical applications," Prog. Polym. Sci., vol. 39, no. 9, pp. 1644-1667, 2014.

[11] T. R. A. Sobahi, M. Y. Abdelaal, and M. S. I. Makki, "Chemical modification of Chitosan for metal ion removal," Arab. J. Chem., vol. 7, no. 5, pp. 741-746, 2014.

[12] T. Lestari, A. Sjaifullah, and A. B. Santoso, "Sintesis dan Karakterisasi Hidrogel Berbasis Kopolimerisasi Cangkok Akrilamida pada Kitin Hasil Isolasi Secara Enzimatis dari Limbah Udang Synthesis and Characterization of Graft copolymerization of Acrylamide Hydrogels Based on the results of Isolation C," J. Ilmu Dasar, vol. 17, no. 2, pp. 59-64, 2016. 
[13] Y. F. Aklog, T. Nagae, H. Izawa, M. Morimoto, H. Saimoto, and S. Ifuku, "Preparation of chitin nanofibers by surface esterification of chitin with maleic anhydride and mechanical treatment," Carbohydr. Polym., vol. 153, pp. 55-59, 2016.

[14] T. Si Trung and H. N. D. Bao, "Physicochemical Properties and Antioxidant Activity of Chitin and Chitosan Prepared from Pacific White Shrimp Waste," Int. J. Carbohydr. Chem., vol. 2015, pp. 1-6, 2015.

[15] Q. Wang, X. Yan, Y. Chang, L. Ren, and J. Zhou, "Fabrication and characterization of chitin nanofibers through esterification and ultrasound treatment," Carbohydr. Polym., vol. 180, no. September, pp. 8187, 2018.

[16] T. Zhong, M. P. Wolcott, H. Liu, and J. Wang, "Propionylation-modified chitin with improved solubility in green ethanol/water binary solvents for sustainable film and coating applications," J. Clean. Prod., vol. 250, no. xxxx, p. 119458, 2020. 